\title{
Study of Weeds as Traditional Medicinal Plants Used by Indigenous People of West Pasaman, Indonesia
}

\author{
Rizki Rizki*1, Nursyahra², Oki Fernando² \\ ${ }^{1}$ Departement of Horticultural Crop Cultivation, Politeknik Pertanian Negeri Payakumbuh, Kabupaten 50 Kota, Indonesia \\ ${ }^{2}$ Departement of Biology Education, STKIP PGRI Sumatera Barat, Padang, Indonesia \\ *Corresponding author: khi_bio@yahoo.com
}

\section{ARTICLE HISTORY}

Received : 23 August 2019

Revised : 8 September 2019

Accepted : 8 October 2019

\section{KEYWORDS}

Ethnobotany

Indigenous Knowledge

Weeds

Medicinal Plant

\begin{abstract}
Ethnobotanical study of weeds as traditional medicinal plants was conducted in West Pasaman, Indonesia. Weed is a type of wild plant that grows naturally without deliberately planted by humans. Weeds grow around housing residents or farmlands. Their existence is less desirable, but indigenous people in Luhak Nan Tigo, West Pasaman, utilize some types of weeds as traditional medicinal plants. This study was focused on identifying weeds as medicinal plants, disease treated, part of the weeds used, methods of preparation, and ingredients added. The descriptive survey method with observation and interview techniques was employed in this study. A total of 35 species of weeds belonging to the 23 plants family were identified. Weeds are used as traditional medicines to cure wounds, fever, bone pain, abdominal pain, back pain, itching, heartburn, asthma, and phlegm.
\end{abstract}

\section{INTRODUCTION}

Ethnobotany is the study of how people in a certain area take advantage of the plants. Plants can be used as food, shelter, medicines, and used in religious ceremonies. (Gonsalves 2010; Maloney 1978; Uddin et al. 2013; Mesfin et al. 2013; Kunwar, 2008). Indigenous people in West Pasaman, Indonesia like other people in other regions, utilize a variety of plants to meet their needs. Interestingly, people in Luhak Nan Tigo use weeds as traditional medicinal plants.

Based on the results of previous research in Pasaman, plants have been long used as a complement in traditional ceremonies. They must exist; otherwise, the traditional ceremony cannot be held In this region, there are 30 species of plants used in traditional ceremonies. In addition to traditional ceremonies, plants are also used as medicines,. However, there have been no reports of the use of wild plants as medicines in this region (Des, Rizki, \& Hidayati, 2018)

Weeds can be used for many things, but their presence in food crop cultivation is considered as pests (Bentley et al. 2005). The presence of weeds can be fatal for the major crops as they do not only slow the growth of crops but they are also potentially harmful to crops (Rahardi 2007). According to Tjahjadi (1989) the adverse effects caused by weeds due to weed competition with the main crop including in absorption of nutrients, water, sunlight - space to grow and so forth.

For indigenous people in Luhak Nan Tigo, Pasaman Barat. Weeds are still used as traditional medicinal plants. Commonly, each plant produces a variety of bioactive molecules through secondary metabolites, such as alkaloids, flavonoids, terpenoids, steroids, and others that are efficacious as medicine (Sudjaji 2004). So, each plant has the potential to be used as medicine. Generally, compounds that are efficacious as medicine in plants are secondary metabolites (Tisnadjaja 2006). Plants producing secondary metabolites are not for the primary needs of life, but as a defense mechanism against infectious diseases and environmental changes. This research aims to find out wild plants as medicines, medicinal plants to be cultivated as well as for further drug research.

\section{MATERIALS AND METHODS}

This research was conducted in West Pasaman, Indonesia. The method used in this research was descriptive survey using observation and interview techniques. The respondents in this study were chosen by employing a purposive sampling technique, where the respondents were those considered most knowledgeable about medicinal plants, their uses, and the medicinal 
compounds in plants.

\section{RESULTS AND DISCUSSION}

As the results of the research, 35 species of plants, including weeds (plants) and included in 23 family were identified. Data of weeds that are used as traditional medicinal plants by indigenous people in Luhak Nan Duo, West Pasaman, is shown in Table 1.

Table 1. Types of weeds used as medicines

\begin{tabular}{|c|c|c|c|c|}
\hline No & Familia & Species & Local Name & Part Used \\
\hline 1 & 2 & 3 & 4 & 5 \\
\hline 1 & Acanthaceae & Asytasia gangetica (L.) T.Anderson. & Tabuang putiah/Ara sungsang & Leaf \\
\hline 2 & Amaranthaceae & Amaranthus dubius Mart. ex Thell. & Bayam tanah & Leaf \\
\hline 3 & Apiaceae & Centella asiatica (L) Urban. & Pigago & Leaf \\
\hline 4 & Aspleniaceae & Asplenium nidus $\mathrm{L}$. & Sikarambai & Leaf \\
\hline \multirow[b]{2}{*}{5} & \multirow[b]{2}{*}{ Asteraceae } & \multirow{2}{*}{$\begin{array}{l}\text { Ageratum conyzoides } \mathrm{L} . \\
\text { Eleutheranthera ruderalis (Sw.) Sch.Bip. }\end{array}$} & Siamih & Leaf \\
\hline & & & Karenyuik & Leaf \\
\hline 6 & Blechnaceae & Stenochlaena palutris (Burm. f.) Bedd & Paku sampang & Leaf \\
\hline 7 & Cyperaceae & Cyperus iria L. & Rumpuik kijang & Root, stem, leaf \\
\hline \multirow[t]{2}{*}{8} & Davaliaceae & Davalia denticulata (Burm.) Mett. & Paku ansam & Leaf \\
\hline & & Phyllanthus niruri L. & Sidukuang anak & Root, stem, leaf \\
\hline \multirow[t]{3}{*}{8} & Euphorbiaceae & & & \\
\hline & & Euphorbia hirta L. & Patikan & Leaf \\
\hline & & Imperata cylindrical (L.) Beauve. & Padang/Alang-alang & Root \\
\hline \multirow[t]{3}{*}{9} & Graminae & & & \\
\hline & & Leersia hexandra Sw. & Rumpuik banto/Kalamenta & Leaf \\
\hline & & Hyptis capitata Jacq. & Siamih busuak/ Bunga Subang-subang & Leaf \\
\hline \multirow[t]{3}{*}{10} & Lamiaceae & & & \\
\hline & & Hyptis suaveolens (L.) Poit. & Nilam mancik/ Gringsingan & Leaf \\
\hline & & Mimosa pudica $\mathrm{L}$. & Sikajuik & Leaf \\
\hline \multirow[t]{2}{*}{11} & Leguminosae & Mucuna pruriens & Kacang miang & Leaf \\
\hline & & Senna alata (L.) Roxb. & Galinggang & Leaf \\
\hline 12 & Loranthaceae & Scurrula ferruginea (Jack). Miq. & Binalu asam & Leaf \\
\hline \multirow[t]{2}{*}{13} & Malvaceae & Sida rhombifolia $\mathrm{L}$. & Siamih rimbo & Leaf, stem \\
\hline & & Clidemia hirta (L.) D. Don. & Sikaduduak rimbo & Leaf \\
\hline \multirow[t]{2}{*}{14} & Melastomataceae & Melastoma malabatricum $\mathrm{L}$. & Sikaduduak & Leaf \\
\hline & & Pternandra echinata Jack. & Sikaduduak air & Leaf \\
\hline
\end{tabular}




\begin{tabular}{|c|c|c|c|c|}
\hline \multirow{3}{*}{15} & \multirow{3}{*}{ Oxalidaceae } & Oxalis barrelieri $\mathrm{L}$. & \multirow[t]{2}{*}{ Kaluwai } & \multirow[t]{2}{*}{ All parts of the plant } \\
\hline & & & & \\
\hline & & Oxalis corniculata $\mathrm{L}$. & Кири-kири 3 jurai & All parts of the plant \\
\hline 16 & Piperaceae & Piper aduncum L. & Siriah rimbo/siriah hantu & Leaf \\
\hline 17 & Polygalaceae & Polygala paniculata $\mathrm{L}$. & Pincalang putiah & All parts of the plant \\
\hline \multirow{2}{*}{18} & & Nephrolepis sp & Paku jantan & Leaf \\
\hline & & Drymoglosum boiled in (L.) Presl. & Siboneh & Leaf \\
\hline \multirow{3}{*}{19} & & Hedyotis auricularia $\mathrm{L}$. & Simolik & Leaf \\
\hline & Rubiaceae & & & \\
\hline & & Mitracarpus hirtus & Daun samak & Leaf \\
\hline 20 & Solanaceae & Physalis angulata $\mathrm{L}$. & Latuik-latuik & Root, leaf \\
\hline 21 & Sterculliaceae & Kleinhovia hospita L & Tumaha & Leaf \\
\hline 22 & Urticaceae & Laportea interrupta (L.) Chew. & Jilatang ayam & Root \\
\hline 23 & Verbenaceae & Stachytarpheta indica (L) Vahl. & Bujang kalam & Leaf \\
\hline
\end{tabular}

\section{Directly without any mixture}

\section{a. Ageratum conyzoides L.}

Local name: Siamih (Badotan) Disease treated: Wounds (to stop bleeding), and fever. Methods of preparation: To treat wounds, the leaves are crushed and placed on the wound. To treat fever, use the leaves, and some water is added and then leaves are squeezed. The juice of the leaves is strained and the juice is consumed as much as one cup (200 ml) twice a day. This plant is used as medicine for sharp wounds by the people in the village of Oo Parese, Central Sulawesi. This plant is processed by squeezing the leaves, and then the squeezed leaves are affixed to the body with bleeding wounds (Yulia, Fahri, \& Ramadani, 2017). The community in Hafizabad District in Pakistan uses this plant for wounds, fever, flu, cough, infertility, jaundice, hair tonics, conjunctivitis, and abdominal pain. This drug is used oral, topical and eye drops. The leaves are processed as extract, stew, powder, and juice (Umair, Altaf, \& Abbasi, 2017)

b. Eleutheranthera ruderalis (Sw.) Sch.Bip. Local name: Karenyuik (Babadotan) Disease treated:
Wounds (to stop bleeding) Methods of preparation: The leaves are crushed and placed on the wound. The decoction of this plant can increase milk production for breastfeeding mothers and can treat high blood pressure (Boggan et al., 1997)

\section{c. Clidemia hirta (L.) D. Don.}

Local name: Sikaduduak rimbo (Senduduk bulu) Disease treated: Wounds (to stop bleeding) Methods of preparation: The leaves are crushed and put on the wound. The twig can be used to relieve menstrual cramps Leaves can reduce scars, boiled water can be used as an antidysenteric and antispasmodic, leaves macerated with cold water can be used as an antiseptic in the female genital area, and can also be used to treat bleeding, The decoction of this plant can also be used to treat stomach pain (Boggan et al., 1997)

\section{d. Melastoma malabathricum L.}

Local name: Sikaduduak (Senduduk) Disease treated: Wounds (to stop bleeding). Methods of preparation: The leaves are crushed and placed on the wound. In Nicobarese/Andaman \& Nicobar Islands, it is used for 
body aches and breathing difficulty (Umair et al., 2017)

e. Pternandra echinata Jack.

Local name: Sikaduduak aia. Disease treated: Fever. Methods of preparation: Using water, the leaves are squeezed then the juice of the leaves is strained. The juice of the leaves is used to compress the patient's forehead. This plant is also found in Tembeling Forest Reserve, Jerantut, Pahang used for coughs and asthma (Eswani \& Abd, 2010)

\section{f. Sida rhombifolia L.}

Local Name: Siamih rimbo (Sidaguri) Disease treated: Pain in bones and joints. Methods of preparation: the leaves and stems are boiled in water. And then let the water cool. The water is used for bath twice a day. In India, this plant can be used as an inflammation drug, increase immunity, for the vitality of adult men. Some tribes in India use this plant for the treatment of gout, rheumatism, kidney disorders and venereal diseases (Abat, Kumar, \& Mohanty, 2017)

g. Hyptis suaveolens (L.) Poit.

Local name: Nila mancik (Gring-singan) Disease treated: Stomach aches. Methods of preparation: it's theThe leaves are squeezed with water and the juice is consumed in the amount of $200 \mathrm{ml}$ three times a day. This plant has antioxidant properties that are tested with DPPH radical scavenging assay (Narayanaswamy \& Balakrishnan, 2011).

\section{h. Hedyotis auricularia L.}

Local name: Simolik. Disease treated: Lumbago. Methods of preparation: The leaves are squeezed with water and the juice in the amount of $200 \mathrm{ml}$ is consumed twice a day. In China, the leaves of this plant are used to cure fever, to remove toxins from the body, to treat the digestive tract, to reduce coughing, colds, to multiply blood cells and to stabilize circulation (Jin, Liu, Xie, Luo, \& Long, 2018)

i. Imperata cylindrica L.

Local name: Alang-alang. Disease treated: Fever. Methods of preparation: The roots were crushed, and some water is added before squeezing the roots. The juice of the roots is strained, and a cup of $200 \mathrm{ml}$ of juice is drunk three times a day. This plant is used for Tonic, cut and wounds, urodynia, hypertension, and febrifuge in Hafizabad district, Punjab-Pakistan (Umair et al., 2017)

\section{j. Mucuna pruriens L.}

Local name: Kacang miang. Disease treated: Stomach aches. Methods of preparation:

The leaves are squeezed using water. The strained juice of the leaves is consumed in the amount of $200 \mathrm{ml}$ twice a day. In Virginia Islands, this plant is hot water extracted, and the entire plant is taken orally for worms (Ross, 2013).

\section{k. Leersia hexandra Sw.}

Local name: Rumpuik banto (Kalamenta). Disease treated: Lumbago. Methods of preparation: The leaves are squeezed with water and by adding a chicken egg yolk, the strained juice is consumed in the amount of $200 \mathrm{ml}$ twice a day. This plant is used as traditional medicines to treat many diseases including hypertension (Bilanda et al., 2019)

l. Laportea interrupta (L.) Chew.

Local name: Jilatang ayam. Disease treated: Dermatitis (Biriang-local name). Methods of preparation: Using some water, the roots are boiled until reaching the boiling point. After that, let the water until it is cold. The water is used to shower twice a day. The juice is to be consumed one cup (200 ml) twice a day. This plant has been widely used by people in the Western Ghat region, India. It is the young plant used for healing various diseases. The leaves are also used for food by residents of Kerala. This plant is also an antimicrobial and shows anti-inflammatory properties (Selvam, Kr, \& Mv, 2016).

\section{With the mixture, as a blend. Weeds can be used as medicines as follows:}

a. Stomach aches

Recipe 1

The tweeds used are the leaves of Paku ansam (Davallia denticulata (Brum.) Mett.), Rumpuik kijang (Cyperus iria L.), daun samak (Mitracarpus hirtus), and Simolik (Hedyotis auricularia L.). All ingredients are boiled. The boiled ingredients water is consumed one cup (200 ml) three times a day.

Recipe 2

Weeds used are the leaves of siamih busuak (Hyptis capitata L.). As a medicine, this plant is mixed with seven pieces of betle leaves (Piper betle L.). Both ingredients are brewed with hot water and consumed one cup (200 ml) three times a day.

b. Fever

Recipe 1

Weeds used are the leaves of Paku air (Diplazium esculentum (Retz). Sw.). To cure fever, this plant is mixed with five leaves of sidingin (Kalanchoe pinnata (Lmk) Pers.), five leaves of Sitawa (Costus speciosa (Koeing) Smith.) and water. Then all the ingredients are squeezed and filtered, and the juice is consumed one cup (200 $\mathrm{ml}$ ) twice a day.

\section{Recipe 2}

The leaves of Sikarambai (Asplenium nidus L.), Paku jantan (Nephrolepis sp), Paku sampang (Stenochlaena palutris (Burm. f.) Bedd), and Tumaha (Kleinhovia hospita L.) are used In using these weeds as a medicine, these plants are mixed with the leaves of Beringin (Ficus benjamina L.) and the root of Dadok (Erythrina variegate L. Var. Orientalis L.). All the ingredients are cut into small pieces and dried then boiled in water. Let the boiling water cool for a few hours, then the water used to bathe. 


\section{c. Lumbago}

Recipe 1

Weeds used are the leaves of Benalu asam (Scurrula ferruginea (Jack).Miq.) and the leaves of Pegagan (Centella asiatica L.). In using these weeds as medicine, these plants are mixed with the leaves of ampadu tanah (Andographis paniculata Ness.) and the Mengkudu fruit (Morinda citrifolia L.). All the ingredients are cut into small pieces and boiled, and the boiled ingredients water as much as one cup (200 ml) is consumed with a frequency of twice a day.

\section{Recipe 2}

Weeds used are all parts of Sidukuang anak (Phyllanthus niruri L.) and Latuik-latuik (Physalis angulata L.). All the ingredients are cut into small pieces and boiled and the boiled ingredients water is consumed one cup (200 ml) twice a day.

\section{d. Gastritis and Lumbago}

Weeds used are some leaves of Binalu asam (Scurrula ferruginea (Jack).Miq.), Galinggan (Senna alata (L.)Roxb.) and sikaduduak (Melastoma malabathricum L.). In using these weeds as a medicine, they are mixed with the stem of Aka ali-ali (Tinospora crispa Miers. Hook. f. \& Thems.), Temulawak (Curcuma xanthoriza Roxb.) and the stem of Tebu hitam (Sacharum officinarum L.). All the ingredients are cut into small pieces and dried and then boiled. The boiled ingredients water in the amount of one cup (200 $\mathrm{ml}$ ) is consumed twice a day.

\section{e. Asthma}

Weeds used are the stem of Patikan (Euphorbia hirta L.), the leaves of Bujang kalam (Stachytarpheta indica (L) Vahl.), the leaves of Tabuang putiah (Asytasia gangetica (L.)T.Anderson.), the leaves of Sikajuik (Mimosa pudica L.), the leaves of Kalimayie (Elephantopus tomentosus L.) and Pincalang putiah (Polygala paniculata L.) All ingredients are boiled and then boiled ingredients water is consumed one cup (200 ml) twice a day.

\section{f. Bone pains}

Weeds used are all parts of Padang (Imperata cylindrica L.) and the leaves of Benalu asam (Scurrula ferruginea (Jack). Miq.). In using these weeds as medicine, they are mixed with Kunyit (Curcuma domestica Val.), Temulawak (Curcuma xanthoriza Roxb.), the fruit of Mengkudu (Morinda citrifolia L.), dan the leaves of Sirsak (Annona muricata L.). All the ingredients are cut into small pieces and boiled in water. one cup (200 ml)of water is to be consumed twice a day.

\section{g. Itchy}

Weeds used are some leaves of Galinggang (Senna alata (L.)Roxb.), and Siboneh (Drymoglosum piloselloides (L.) Presl.). In using these weeds as medicine, these plants are mixed with the leaves of Anau (Arenga pinnata Merr.). All ingredients are crushed and blended. Then it is applied to the body. h. Joint and bone pains

The weeds used are some leaves of Siamih busuak (Hyptis capitata Jacq.) and Siriah rimbo (Piper aduncum L.). All the ingredients are boiled, let the boiling water for a few hours, then it is used to bathe. To be used twice a day.

\section{i. Phlegm}

To cure the phlegm, the leaves of Bayam tanah (Amaranthus dubius Mart. ex Thell.) are used. In using this weed as medicine, it is mixed with the leaves of daun Sirih (Piper betle L.) All ingredients are crushed and blended and applied to the body.

\section{CONCLUSION}

Shown here are 35 species of weeds belonging to the 23 plants family, namely Achantaceae, Amaranthaceae, Apiaceae, Aspleniaceae, Asteraceae, Blechnaceae, Cyperaceae, Davaliaceae, Euphorbiaceae, Graminane, Lamiaceae, Leguminosae, Loranthaceae, Malvaceae, Melastomataceae, Oxalidaceae, Piperaceae, Poligalaceae, Polypodiaceae, Rubiaceae, Solanaceae, Sterculiaceae, Urticaceae and Verbenaceae. Weeds are used as traditional medicines to cure wounds, fever, bone pain, abdominal pain, back pain, itching, heartburn, shortness of breath, and phlegm.

\section{REFERENCES}

Abat, J. K., Kumar, S., \& Mohanty, A. (2017). Ethnomedicinal, Phytochemical and Ethnopharmacological Aspects of Four Medicinal Plants of Malvaceae Used in Indian Traditional Medicines: A Review. Medicines, 4(4), 75.

Bilanda, D. C. A. A. of L. hexandra S. (Poaceae) A. E. on E., Tcheutchoua, Y. C., Djomeni Dzeufiet, P. D., Fokou, D. L. D., Fouda, Y. B., Dimo, T., \& Kamtchouing, P. (2019). ol-Induced Hypertension in Wistar Rat. Evidence-Based Complementary and Alternative Medicine, 2019, 1-9.

Boggan, J., Funk, V., Kellof, C., Hoff, M., Cremers, G., \& Feuillet, C. (1997).Checklist of the plants of the guianas (Guyana, Surinam, French Guiana). Smithsonian, 245.

Des, M., Rizki, R., \& Hidayati, H. (2018). Ethnobotany in Traditional Ceremony at Kanagarian Sontang Cubadak Padang Gelugur Subdistrict, Pasaman District. In IOP Conference Series: Materials Science and Engineering (Vol. 335, No. 1, p. 012018). IOP Publishing.

Eswani, N., \& Abd, K. (2010). Medicinal Plant Diversity and Vegetation Analysis of Logged over. Journal of Agricultural Science, 2(3), 189-210.

Jin, B., Liu, Y., Xie, J., Luo, B., \& Long, C. (2018). Ethnobotanical survey of plant species for herbal tea in a Yao autonomous county (Jianghua, China): Results of a 2-year study of traditional medicinal markets on the Dragon Boat Festival. Journal of Ethnobiology and Ethnomedicine, $14(1)$.

Narayanaswamy, N., \& Balakrishnan, K. P. (2011). Evaluation of some medicinal plants for their antioxidant properties. International Journal of Pharm Tech Research, 3(1), 381-385.

Ross, I. A. (2013). Mucuna prurlens (L) DC. In Medicinal Plants of the World, vol. 7: Chemical Constituents, Traditional and Modern Medicinal Uses, 2nd ed. (Vol. 7, pp. 305-314).

Selvam, N. T., Kr, S., \& Mv, A. (2016). Ethnomedicinal Value of Laportea interrupta L . Chew: A Review. International Journal of Pharma Sciences and Research (IJPSR), 7(5), 245-249.

Umair, M., Altaf, M., \& Abbasi, A. M. (2017). An ethnobotanical survey of indigenous medicinal plants in Hafizabad district, Punjab-Pakistan. PLoS ONE, 12(6), 1-22.

Yulia, C., Fahri, \& Ramadani. (2017). Studi Etnobotani Tumbuhan Obat Suku "Topo Uma" Di Desa Oo Parese Kecamatan Kulawi Selatan Kabupaten Sigi Sulawesi Tengah. Biocelebes, 12(2), 1-22. 